\title{
The effect of personal health on the formation of human capital: a metasystem approach
}

\author{
M.V. Sokolskaya ${ }^{1}$, A.G. Madzhuga ${ }^{2}$, N.S. Babieva ${ }^{3}$, K.O. Khvostunov ${ }^{4}$, \\ A.V. Moskvina ${ }^{5}$, L.B. Abdullina ${ }^{6}$, R.V. Kanbekova ${ }^{7}$, R.M. Salimova ${ }^{8}$, E.V. Golovneva9 \\ ${ }^{1}$ Department of Social Sciences and Humanities, Far Eastern State Transport University, Russia \\ 2,67,8,9 Department of Psychological and Pedagogical Education, Sterlitamak Branch of the Bashkir State, Russia \\ ${ }^{3,4}$ Department of Nursing Management and Social Work, First Moscow State Medical University, Russia \\ ${ }^{5}$ Department of Special Pedagogy and Training Methods, Orenburg State Pedagogical University, Russia
}

\section{Article Info \\ Article history: \\ Received Jan 16, 2019 \\ Revised Feb 21, 2019 \\ Accepted Feb 27, 2019 \\ Keywords: \\ Human capital Metasystem approach \\ Personality's health \\ Professional health \\ Spiritual health}

\begin{abstract}
In article the problem of influence of the personality's health on formation of the human capital is considered. Authors have conducted theoretical researches of the existing knowledge of the human capital and justifications of influence of the personality's health on its formation are given. On the basis of the carried-out analysis it is established that now the personality's health is a significant factor of efficiency of any kind of activity and important quality of the personality, therefore, it can be considered as a factor of formation of the human capital. According to it need of determination of criteria, the indicators of health of the personality influencing formation and development of the human capital was designated.
\end{abstract}

Copyright $\odot 2019$ Institute of Advanced Engineering and Science. All rights reserved.

\section{Corresponding Author:}

Madzhuga Anatoly Gennadievich, Department of Psychological and Pedagogical Education,

Sterlitamak Branch of the Bashkir State,

Lenin Ave, 49, Sterlitamak, 453100, Russia.

Email: madzhuga.anatolijl@inbox.ru

\section{INTRODUCTION}

Basic change of a role and value of a human factor in economy and society is characteristic of the present stage of world scientific and technical and social and economic development. The human capital becomes the most important factor of economic growth and social development of society. Many states displace an influence dominant from growth rates of national economy on development of the personality's healthy, education of the healthy population now. In this regard health of the personality acts as a measure of quality of life of people and policy of the state. Respectively the processes happening in modern society demand turn of psychological sciences to the comprehensive analysis and intensive judgment of the human capital and one of its main components-the capital of health.

But it is necessary to recognize that many significant aspects of a perspective of health are investigated obviously insufficiently today. The former concepts and explanatory schemes which are giving limited interpretation of a phenomenon of health, reducing all variety of his manifestation to biological or psychophysiological models are recognized not as corresponding to the modern level of natural-science and humanitarian knowledge of the person (O.S. Vasilyeva, D. Vutulkas, Kaznacheev V. P., E.A. Spirin, Rozin V.M.) today. Therefore certain attempts to meet the formed lack, to reveal the new or a little studied aspects of measurement of health connected with fundamental problems of human existence are made. In particular, scientific interest in a problem of social regulation of health (I.M. Gurvich), its sociocultural 
and social and psychological determination considerably increases (I.V. Zhuravlyova, O.V. Obidin, O.V. Koroteyeva, N.I. Ryazanova, Filatov F. R.).

The following paradox is revealed: despite relevance of a problem of maintenance of health, in most cases at people the need for preservation and promotion of health isn't created. Population attitude researches towards own health show that only $30 \%$ of respondents estimate a condition of the health as "rather good than bad". However, in most cases, citizens don't ask for the help experts, explaining it as follows: "I consider that the disease will pass by itself, without treatment, not to pay attention to a condition of the health, I am afraid that the disease can entail negative attitude from the management, I am afraid of material inputs", etc. And only in any cases ask for the help experts about 15\% [1].

In the 20th century the psychology has passed a long way in studying of the human capital: from allocation of psycho physiological properties of individuals of driver's and "conveyor" professions through accounting of "ergonomic" properties of operators of ACS to the psychologic-acmeological characteristic of personal and competence-based qualities of various professionals (from experts to top managers) in modern contours of management [2]. The category "human capital" represents a difficult, multiple-factor social-psychological concept. The most important instrument of reproduction of the human capital are social institutes, from a state and which development process of reproduction of the person as a social being on accumulation of a certain stock of health, knowledge, skills, motivations, professional competence and the acquired qualification depends.

In practice of a research of the human capital cross-disciplinary approaches to studying of development of the person from the point of view of his ability to accept global changes and to successfully use them for themselves and society are insufficiently widely applied. Knowledge of the person is incomplete, scattered on numerous areas of knowledge that the human capital leads to fragmentariness of empirical estimates. Psychological measurement of the human capital has appeared as development of the psychodiagnostic methods of professional selection constructed on theoretical concepts of representatives of the Leningrad psychological school (B.G. Ananyev, V.A. Ganzen, G.V. Sukhodolsky).

There is not simple situation with a problem of a research of the personality's health-in spite of the fact that this is a subject of studying of various sciences-medicine, psychology, sociology, economy, etc., but still these researches have no rather complex, system character [4, 9-12, 15]. As criteria of the healthy personality are allocated: viability (Maddi S. Hosseini Z., Aghamolaei T., Ghanbarnejad A.), energy potential (B.G. Ananyev, D.A. Leontyev); special modality of consciousness (S.L. Rubenstein, K.A. Abulkhanov-Slavskaya) [7].

Considerable specific weight is got by psychological researches of various factors and determinants of the personality's health, values and purpose-in-life orientations are investigated (T.V. Sushchenko, Solomonov V. A., T.V. Belinskaya); spiritual and moral determinants of safe development (O.I. Danilenko, A.V. Sakhno). Health is considered in the light of the concept of "a consciousness vertical" (B.S. Bratus), in acmeology (A.A. Bodalyov, A.A. Rean), in the long term limit opportunities and the highest achievements of human spirit (Ponomarenko V. A., F. Syahrul, U.W.Chatarina, A. Hargono). Health of the personality is defined and as the system quality characterizing the personality in its integrity (G. Zafiropoulos , I.V. Dubrovina, Kaliteevskaya E.R., Yu.M. Orlov) and as "a structure-forming construct of the spiritual sphere of mankind" (Bodalyova. And.); as metasystem quality of the personality (M.V. Sokolskaya, Karpov A.V.); as the characteristic of working capacity-professional health (G.S. Nikiforov, Ananyev V. A.), which are offered by authors according to requirements of different types of social practice $[3,5,6]$.

The foregoing has allowed formulating the aim of the research-to study a role of health of the personality in formation of the human capital. Object of research is the personality's health in structure of the human capital. Subject of research-a role of the factors of health of the personality promoting formation of the human capital. While developing a perspective of a research the main approaches to understanding of the healthy personality and criteria of health by representatives of the western humanistic, existential psychology were used (Rogers K., V. Frankl, A. Adler, A. Maslou, E. Fromm, Eriksson E., etc.), modern theoretical approaches and empirical researches of psychology of health (V.A. Ananyev, B.S. Bratus, D.A. Leontyev, Ponomarenkov. And., I.I. Brekhman, M.V. Sokolskaya, A.G. Madzhuga, etc.). Works of founders of the theory of the human capital of G. Becker and T. Schultz; works of the domestic sociologists considering problems of preservation, accumulation and development of the human capital of modern Russia (Zaslavskayat. And., R.V. Ryvkina, Z.T. Golenkova, V.V. Radayev, V.A. Yadov, Magong V.S.).

The important role was played also by that factor that the understanding of features of course of development of the personality in the system of its activity gives a complete idea of the person. In line with this research health of the personality is considered as an optimum prerequisite (conditions) for performance by the person of the planned vital purposes and tasks, its purpose and eventually of its self-implementation $[13,14]$. The main sense of health consists in finding by the person of vital comfort, 
wellbeing, then a main objective of health-identification and maintenance of resources of the personality for realization of its vital mission.

\section{RESEARCH METHOD}

For achievement of the goal of a research and the solution of objectives the following methods were used: general scientific methods of the social and psychological description: the system method allowing to consider a research object in the form of system, to analyze interaction of elements of system; the comparative analysis consisting in studying of the materials presented in research literature, their analysis and comparison.

At the present stage concrete attempts to create complete scientific idea of a phenomenon of the personality's health are made by both foreign and domestic psychologists. As characteristics of the healthy personality such concepts as are used: "force I, the personal potential, spiritual health, a personal maturity, viability", however, all these characteristics define an opportunity and ability of the personality to overcoming, opposition to vital difficulties whereas personal health, on the contrary, characterizes the balanced, harmonious living arrangement of the personality, ability to redistribute not only own forces and means (resources) between various parties of activity, but also to change the direction of personal development: not to concentrate on destructive, in time to leave the activity destroying the personality; ability to set the alternative purposes, to find kinds of activity, perspective for development. All this gives the grounds to consider these concepts of quality of base for designation of the integrated personal characteristic-personal health.

Health of the personality, thus, acts as a vital sign of the mature, viable personality having personal potential. On the one hand, being formed on the basis of these qualities, personal health represents the highest level of personal characteristics, and with another, owing to the fact that personal health is presented in all these qualities, and they, in turn, are manifestation, expression of personal health which is, perhaps, is paramount important when forming the human capital. The human capital as a multidimensional phenomenon is non-uniform, has complex internal structure concerning which consent among scientists is also not reached as researchers differently connect a concept of the human capital with the living human person. Distinctive feature of the human capital-inseparability from the identity of the carrier. The human capital can't be separated from the specific person and to transfer to other owner, it can depreciate, be exhausted (to degrade) in connection with physical wear of the person or as a result of moral obsolescence of knowledge and skills.

In the context of a perspective of this research health can be considered, on the one hand, as the consumer benefit for which demand is shown, and, on the other hand, as the investment benefit which is determined by the net value of the benefits received from this benefit. For example, increase in life expectancy means addition of the additional periods of work during which the person gains income and invests in the capital. Level of health of the personality depends also on quality of services of health care which accompanies the person since the birth. Certainly, the less disease exist, the level of health of the population and return from capital investments in health care is higher. Recently the special alarm is caused by a condition of mental health of the population of Russia since the intellectual potential of the country, the nation; development of productive forces and manpower are directly connected with him. Specific weight of patients such increases. Many mental diseases are equivalent the death of the person from the point of view of opportunities of realization of the human capital.

Due to the foregoing, it is possible to define two main arguments in favor of need of consideration of category health as one of the main components of the human capital: 1) Improvement of health of the population increases labor productivity level and reduces expenses from disability owing to incidence or disability, 2) Investments into health care promote decrease in the depreciation of the human capital connected with aging of a human body and also increase the period of working-age of the population. But from whatever positions scientists approached definition of the concept "health", their main interest is concentrated on identification of those mechanisms which provide normal activity of an organism, its reliability as complete system.

Results of researches of the last decade demonstrate that health of the person only for 8-10\% depends on health care, for $20 \%$-from ecological conditions,- is defined on $20 \%$ by genetic factors, and for $50 \%$ health of the person depends on a way of life of the person (a rational daily regimen, use of various methods of the fastest convalescence and stimulation of working capacity, hygiene of a balanced diet, disposal of addictions and excessive weight, prophylaxis and elimination of stresses) [1]. Psychological (internal) and social (external) factors of health of the person have not smaller value. And in each of the called factors health of the person has features of the implication. If questions of prophylaxis of health, strengthening of protective forces of an organism and treatment of illnesses are in the field of attention of

The effect of personal health on the formation of human capital: a metasystem approach (M.V. Sokolskaya) 
traditional medicine for a long time, then integrated idea of essence and ways of ensuring the health bound to psychological and social factors didn't develop yet.

Social factors of health of the person are defined as quantity and quality of interpersonal communications of an individual and extent of his participation in life of society. Psychological factors of health of the person out of the system of the public relations in which this person is included just don't exist. The person appears at this level first of all as a being public, and in this case to the forefront there are questions of influence of society on health of the person. Consequences of these influences can be for health of the person both are favorable, and are adverse. Only people with healthy mentality usually feel like active participants of social system; sincere health can be defined how the involvement into communication, into social interaction.

Among the social factors of health of the personality exerting special impact on formation of the human capital, the leading role is assigned to professional activity and the family relations. Refer to other social factors: ability to preserve and keep in touch with friends; ability to adjust good relationship with other people; thoughtfully organized, versatile, it is informative also emotionally rich leisure, with reasonable inclusion in it's of improving practice. Mental balance is considered the most important criterion of health. This criterion is organically connected with two others: harmony of the organization of mentality and its adaptive opportunities. The measure of steadiness of the person and objective conditions, his fitness, adaptedness to them depends on degree of expressiveness of mental balance.

American psychologist A. Ellis has tried to define criteria of social factors of health. He has carried to them: interest in, public interest, self-checking, flexibility, adoption of uncertainty, orientation to creative plans, scientific thinking, responsibility for the emotional violations, high frustration stability. Domestic psychologists complement this list with such criteria as the culture of consumption, altruism, empathy, unselfishness, democratic in behavior. The social illness can be caused by such personal properties as conflictness, egocentrism, communicative domination (the aspiration to impose the point of view, to interrupt in a conversation of the interlocutor, to be the focus of attention). The problem of spiritual health is of particular importance. Many experts in the field of medicine consider that spiritual health should be preserved first of all. The modern official medicine carries the psychosomatic, i.e. originating in mental disharmony about $80 \%$ of all diseases to number.

There are allocated a number of signs of spiritual health (strength of mind): positive outlook on life and internal balance; ability to concentration; ability to bridle negative emotions; high level of social activity; understanding of persons and situations; ability to isolate the most important of a set unimportant; vegetative stabilization; attentiveness and concentration; ability to listen and hear, look and see, to choose itself and to choose to itself; ability of orientation which allows the person to take an adequate position in the world surrounding us. The analysis of a psychological component of these signs allows to connect strength of mind with rather high development of strong-willed qualities and ability to self-control.

\section{RESULTS AND DISCUSSION}

Thus, considering the category of health as one of the main components of human capital is determined by a number of conceptual grounds: 1) Improvement of health of the population increases labor productivity level and reduces expenses from disability owing to incidence or disability, 2) Investments into health care promote decrease in the depreciation of the human capital connected with aging of a human body and also increase the period of working-age of the population.

Identification of a role of health of the personality in formation of the human capital was a main objective of the undertaken research. As have shown results of a research-distinctive feature of the human capital-inseparability from the identity of the carrier, respectively, the benefit for the personality-the benefit for the human capital. It is possible to include rather volume list in the maintenance of the concept "benefit", and the health defining quality of activity of the personality will be one of the major.

\section{CONCLUSION}

The conducted research allows drawing a number of conclusions: 1) The human capital as a multidimensional phenomenon is non-uniform, has complex internal structure. Formation of the human capital is the process having the cyclic form during which the human capital makes the functional revolution which is carried out in the course of activity by owners of the human capital. 2) Distinctive feature of the human capital-inseparability from the identity of the carrier. The human capital can't be separated from the specific person and to transfer to other owner, it can depreciate, be exhausted (to degrade) in connection with physical wear of the person or, on the contrary, to develop in better, effective (the special importance of category of health from this follows when forming the human capital). 3) Health of the personality acts as 
a vital sign of the mature, viable personality having personal potential. On the one hand, being formed on the basis of these qualities, health of the personality represents the highest level of personal characteristics, and with another, owing to the fact that health of the personality is presented in all these qualities, and they, in turn, are manifestation, expression of health which is, perhaps, is paramount important when forming the human capital. 4) Health of the personality is formed by two main categories of determinants-internal and external. The internal category is made by determinants of actually personal plan: social orientation, self-control, aspiration to self-updating which provide formation of personal health as characteristics of the personality in general, the external category of determinants includes factors of the activity plan: the type of professional activity and a stage of professionalizing providing formation of the identity of the professional and level of professionalism and, respectively, formation of personal health. 5) Social factors of category health are defined as quantity and quality of interpersonal communications of an individual and extent of his participation in life of society. Psychological factors of health of the personality out of the system of the public relations in which this personality is included just don't exist. The person appears at this level first of all as a being public, and in this case to the forefront there are questions of influence of society on health of the personality.

\section{ACKNOWLEDGEMENTS}

The authors are grateful to German Sergeevich Nikiforov, Doctor of Psychological Sciences, Professor of St. Petersburg State University, for his significant contribution to the development of a new direction in the field of applied Russian psychology-health psychology. The authors are grateful to the editor-in-chief and members of the editorial board of the journal for the opportunity to publish the results of their research.

\section{REFERENCES}

[1] Nikiforov, G.S. Psychology of health in Russia: formation and current state//Bulletin of St. Petersburg university. Series 16: Psychology. Pedagogics. 2012. No. 1. Page 38-47.

[2] Semyonov I.N. Human and social capital: cross-disciplinary and reflexive and psychological aspects of interaction//Modernization of economy and globalization. Book 2. M. Prod. HSE house. 2009. Page 431-441.

[3] Sokolskaya M.V., Karpov A.V. Psychology of personal health of the professional: Metasystem approach: monograph. Khabarovsk, 2017, 559 pages.

[4] Dye St. Can mental health clusters be replaced by patient typing?//British Journal of Healthcare Management .2017.-Vol.23.-№.5.-P.229-237. https://doi.org/10.12968/bjhc.2017.23.5.229

[5] Zafiropoulos G. Educational programmes: Saving money in healthcare// British Journal of Healthcare Management. -2015.-Vol.21.-№.12.-P.571-576. https://doi.org/10.12968/bjhc.2015.21.12.571

[6] Fariani Syahrul, Chatarina U. W., Arief Hargono. The Establishment of Child Health Cadre as Prevention for Foodborne Disease at Primary Schools //International Journal of Public Health Science (IJPHS).-2017.-Vol.6.№.2.-P. 151-156. DOI: http://dx.doi.org/10.11591/.v6i2.6646

[7] Hosseini Z., Aghamolaei T., Ghanbarnejad A. Prediction of Health Promoting Behaviors Through the Health Locus of Control in a Sample of Adolescents in Iran, Health Scope.-2017-№ 6(2).-P.39-43. DOI: 10.5812/jhealthscope.39432.

[8] Cheon J., Lee S., Crooks S. M., Song J. An investigation of mobile learning readiness in higher education based on the theory of planned behavior//Computers \& Education 59(3).-2012.-P. 1054-1064. DOI: http://dx.doi.org/10.1016/j.compedu.2012.04.015

[9] Cook B., Wayne G. F., Kafali E. N., Liu Z., Shu C., Flores M. Trends in smoking among adults with mental illness and association between mental health treatment and smoking cessation// The Journal of the American Medical Association.-2014.-311(2). Retrieved from http://jama.jamanetwork.com/article.aspx?articleid=1812961

[10] Leventhal, H., Brisette, I., \& Leventhal, E. A. (2003). The common-sense model of self-regulation of health and illness. In L. Cameron \& H. Leventhal (Eds.), The self-regulation of health and illness behavior (pp. 42-65). London: Routledge. Google Scholar http://scholar.google.com/scholar_lookup

[11] David Greenfield Usman Iqbal Yu-Chuan (Jack) Li. Healthcare improvements from the unit to system levels: contributions to improving the safety and quality evidence base//International Journal for Quality in Health Care.2017.-Vol.29.-№ 3 (1).-P. 313-319. https://doi.org/10.1093/intqhc/mzx054

[12] Madzhuga A.G., Kislyakov P.A., Korjuev A.V., Shurupova R.V., Sokolova A.S., Sadykova A.R. PSYCHOPEDAGOGICAL FOUNDATIONS OF CREATING HEALTH THE RISING GENERATION IN MODERN SOCIOCULTURAL SPACE//Ponte.-2017.-Vol. 73.-№ 8.-P. 234-242.DOI: 10.21506/j.ponte.2017.8.17

[13] Madzhuga A.G., Abdullina L.B., Golovneva E.V., Karpov D.N., Askarova G.B., Filipenko E.V. PERSON'S HEALTH CREATION POTENTIAL AS A RESOURCE OF INTEGRATED HEALTH//Journal of Global Pharma Technology.-2016.-Vol.8.-№8.-P. 24-27. URL: https://elibrary.ru/item.asp?id=29860408

[14] Madzhuga A.G., Sabekiya R.B., Abdullina L.B., Karpov D.N., Salyakhova Z.I. HEALTH AS A CORE CHARACTERISTIC OF HUMAN EXISTENCE //Journal of Global Pharma Technology.-2016.-Vol. 8.-№ 8.-P. 7-11.URL: https://elibrary.ru/item.asp?id=29486042 
[15] Tudor T. Strategic management of waste and resources in health and social care//British Journal of Healthcare Management.-2017.-Vol.23.-№ 1.-P.8-11. https://doi.org/10.12968/bjhc.2017.23.1.8

\section{BIOGRAPHIES OF AUTHORS}

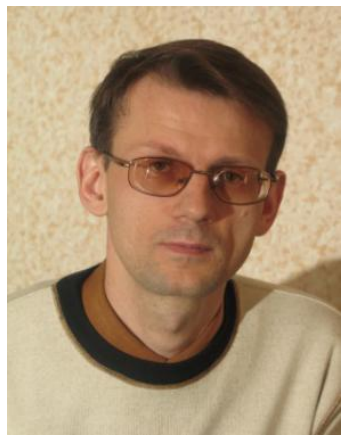

Madzhuga Anatoly Gennadievich, Professor, Department of Psychological and Pedagogical Education, Sterlitamak Branch of the Bashkir State University, Doctor of Pedagogical Sciences, Professor, Full Professor of the European Academy of Informatization (Brussels) Education: 1992-South Kazakhstan State University. M.O. Auezov, naturally the Faculty of Science with a degree in chemistry and biology, 2009-Karaganda State University. E.A. Buketova, specialty: "teacher-psychologist". Academic degrees: 2011-Doctor of Pedagogical Sciences, specialty"13.00.01- general pedagogy, history of pedagogy and education", Vladimir. 2010-academic title "full professor", Brussels (Belgium). 2009-Ph.D. in the field of psychology, Brussels (Belgium).2001-academic title of associate professor in the specialty 03.03.00-biology, Moscow 1999-Candidate of Pedagogical Sciences, specialty "13.00.02- theory and methods of teaching biology", St. Petersburg. Professional interests: health psychology, health pedagogy, pedagogical innovation, acmeology. Publications: Total number of publications-230. Awards 2013-Awarded the highest award of the European Union by the B.Pascal Gold Medal "For basic research in the field of pedagogy and health psychology." 2012 - Awarded the Gold Medal established by the international fund Antonio Meneghetti "for the best scientific research in the field of ontopsychology." Since 2010- member of the dissertation council D 212.012.01 for the degree of candidate and doctor of pedagogical sciences at the Bashkir State Pedagogical University. M. Akmullah.

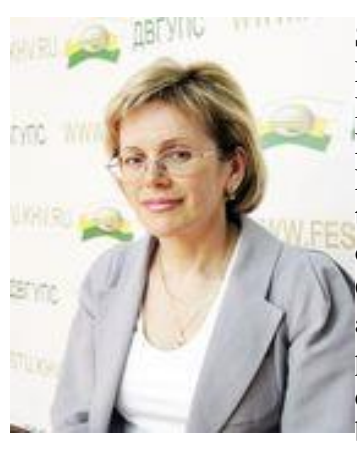

Sokolskaya Marina Vyacheslavovna, Head of the Department of General, Legal and Engineering Psychology, Doctor of Psychology, Professor, Corresponding Member of the Russian Academy of Natural Sciences. Education: 1984 - Kiev Institute of Civil Aviation Engineers, Faculty of Automation and Computer Engineering with a degree in Systems Engineering, 1995 - Khabarovsk Institute of Art and Culture, specialty: "psychologist-social teacher". Academic degrees: 2012 - Doctor of Psychology, specialty - "19.00.03 - psychology of labor, engineering psychology, ergonomics (psychological sciences)", Khabarovsk. 1999 Candidate of Psychological Sciences, specialty "19.00.13 - developmental psychology, acmeology", St. Petersburg. Professional interests: the psychology of the personality of a professional, the psychology of labor, the psychology of personal health, the psychology of development. Publications: Total number of publications - 120. Awards 2007 - Awarded the badge of the Ministry of Education and Science of the Russian Federation "For research work with students." 2009 - Winner of the Award of the Governor of the Khabarovsk Territory in the field of vocational education for a significant contribution to the training of workers and specialists for the industries and social sphere of the Khabarovsk Territory. From 2002 to 2012 Academic Secretary of the Joint Dissertation Council DM 218.003.04 for the degree of candidate and doctor of psychological sciences.

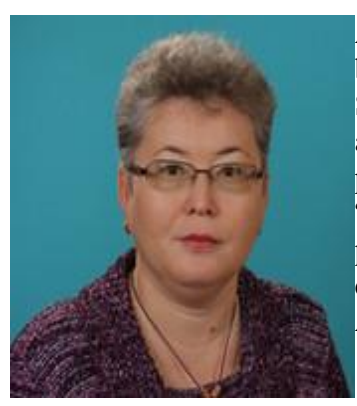

Abdullina liliyaBakirovna, Dean of the Faculty of Pedagogy and Psychology of the Sterlitamak branch of the Bashkir State University, Ph.D., associate professor Education: 1991 - Sterlitamak State Pedagogical Institute, specialty: "primary school teacher". Academic degrees: 2006 academic title of associate professor in the specialty "13.00.01 - general pedagogy. history of pedagogy and education ”, Moscow. 1999 - Candidate of Pedagogical Sciences, specialty "13.00.01 - general pedagogy. history of pedagogy and education, Ufa. Professional interests: primary education pedagogy, theory and methodology of primary education, health pedagogy, developmental psychology.Publications: Total number of publications - 110. Awards 2018 Awarded the title of Honored Educational Worker of the Republic of Bashkortostan.

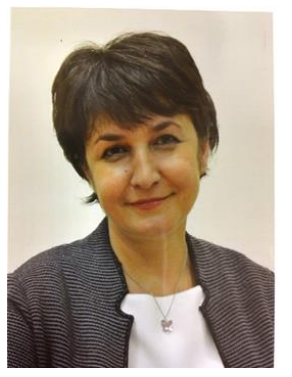

Babieva Nigina Safoevna

Candidate of psychological Sciences, associate Professor of the Department of nursing and social work management Federal state Autonomous educational institution of higher education I. M. Sechenov First Moscow state medical University of the Ministry of health of the Russian Federation (Sechenov University). Education: 1986-Leningrad state pelagic Institute, faculty of defectology. Academic degrees: 2000-candidate of psychological Sciences "19.00.10", St. Petersburg. Professional interests: personality Psychology, Organizational psychology, health Psychology, developmental Psychology, Neuropsychology. Publications: Total number of publications - 56 . 


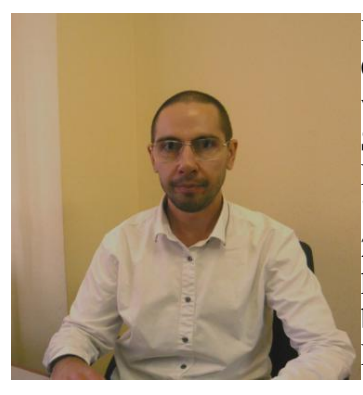

Khvostunov Konstantin Olegovich

Candidate of pedagogical Sciences, associate Professor of the Department of nursing and social work management Federal state Autonomous educational institution of higher education I. M. Sechenov First Moscow state medical University of the Ministry of health of the Russian Federation (Sechenov University). Academic degrees: 2004 - candidate of pedagogical Sciences "13.00.05"- Theory, methods and organization of socio-cultural activities, Tambov. 2009 - academic title of associate professor in the specialty " 13.00 .01 - general pedagogy. history of pedagogy and education ", Moscow. Professional interests: psychology of deviant behavior, addictology, social pedagogy, penitentiary pedagogy, creative technologies. Publications: Total number of publications - about 50 Awards: 2015 - winner of grant competition of the Vladimir Potanin charity Fund for teachers of master's programs

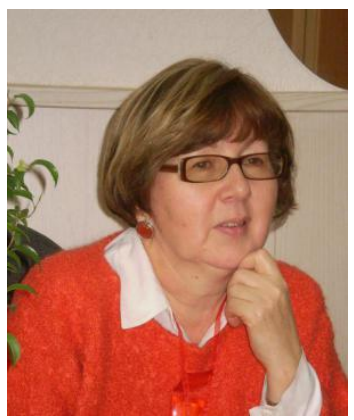

Moskvina Alfiya Valeevna

Professor, Department of Special Pedagogy and Training Methods, Orenburg State Pedagogical University, Doctor of Pedagogical Sciences, Professor Education:

1977- Orenburg State Pedagogical Institute. V.P. Chkalov in the specialty "Russian language and literature". Academic degrees: 2010 - academic title of professor in the specialty "13.00.01 - general pedagogy. history of pedagogy and education ", Moscow. 2006 - Doctor of Pedagogical Sciences, specialty - "13.00.01 - general pedagogy, history of pedagogy and education", Orenburg. Professional interests:inclusive education, integrative processes in the field of education, creative pedagogy, pedagogical askiology Publications: Total number of publications - 145 .

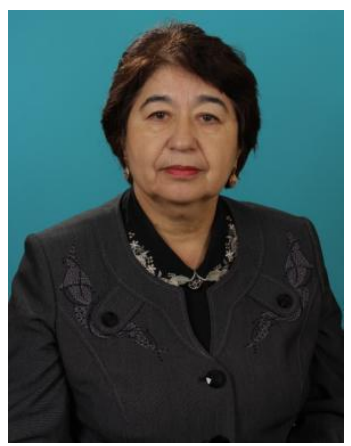

Kanbekova Rimma Valeevna

Professor, Department of Theory and Methods of Primary Education, Sterlitamak Branch of the Bashkir State University, Doctor of Pedagogical Sciences, Professor Education: 1969 -Bashkir State University, Faculty of Physics and Mathematics. Academic degrees: 2003-Doctor of Pedagogical Sciences, specialty-13.00.08-"Theory and methods of vocational education", Moscow. 2010-academic title of professor in the specialty 13.00.08-"Theory and methods of vocational education", Moscow. Professional interests: theory and methods of teaching mathematics in primary school, pedagogical synergy, philosophy of education, innovative educational technologies. Publications: Total number of publications-170. Awards 1993-Excellence in Public Education of the Russian Federation 2002-Honorary Worker of Higher Professional Education of the Russian Federation

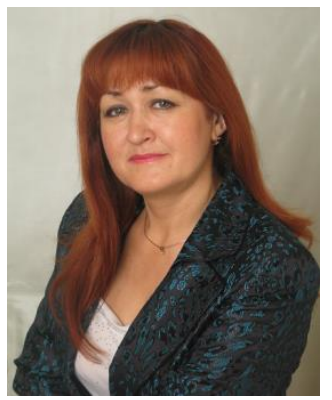

Salimova Roza Mirhatovna

Head of the Department of Psychological and Pedagogical Education of the Faculty of Pedagogy and Psychology of the Sterlitamak branch of the Bashkir State University

Candidate of Pedagogical Sciences, Associate Professor

Education: 1987 - Moscow State Pedagogical Institute named after V.I. Lenin, specialty "Pedagogy and Psychology" Academic degrees: 2000 - Candidate of Pedagogical Sciences, specialty "13.00.01 - General Pedagogy, history of pedagogy and education, Ufa 2005 - academic title of associate professor in the department of psychology Professional interests: developmental psychology, problems of professional training, the problem of individual differences, psychology and health pedagogy. Publications: Total number of publications - 183. Awards 2005 - Excellence in Education of the Republic of Bashkortostan, 2010 - Honorary Worker of Higher Professional Education of the Russian Federation. 


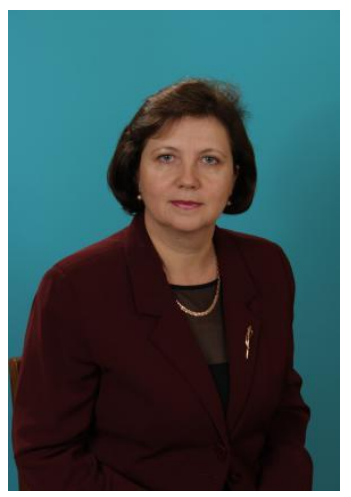

Golovneva Elena Veniaminovna

Professor, Head of the Department of Pedagogy of Primary Education, Sterlitamak Branch of the Bashkir State University, Doctor of Pedagogical Sciences, Professor Education: 1983 - Chelyabinsk State Pedagogical Institute, specialty "History and Pedagogy". Academic degrees: 2005 - Doctor of Pedagogical Sciences, specialty - 13.00.01 - "general pedagogy, history of pedagogy and education", Moscow. 2008 - academic title of professor in the specialty 13.00.01 - "general pedagogy, history of pedagogy and education", Moscow. Professional interests:theory and methods of education in primary school, family education, general pedagogy, innovative educational technologies, media pedagogy. Publications: Total number of publications - 156. Awards: 2010 - Honorary Worker of Higher Professional Education of the Russian Federation. 